\title{
Penile Abscess Due to Intracavernosal Injection: A Case Report
}

\author{
Intrakavernozal Enjeksiyona Bağlı Oluşan Penil Apse: Olgu Sunumu
}

\author{
(D) Yalçın Kızılkan, (1) Mesut Berkan Duran, (1) Çetin Levent Peşkircioğlu \\ Başkent University Faculty of Medicine, Department of Urology, Ankara, Turkiye
}

\begin{abstract}
Penile abscess is a rare clinical entity. We present the case of a 45 -year-old paraplegic male who developed penile abscess due to self-administration of intracavernous papaverine injections for erectile dysfunction treatment. Penile magnetic resonance imaging revealed an abscess of $5 \times 4.5 \mathrm{~cm}$ in size, located at the right side of the penis and the penile corpus deviated to the left side. Penile exploration, incision and drainage were performed and the patient was treated successfully with intravenous antibiotics. A penile prosthesis was implanted 6 months after the initial surgery.
\end{abstract}

Keywords: Penile abcess, Intracavernosal injection, Erectile dysfunction

\section{Öz}

Penil apse ender görülen bir durumdur. Paraplejik ve erektil disfonksiyon nedeniyle intrakavernozal enjeksiyon kullanımına bağlı penil apse gelişen 45 yaşındaki erkek hasta anlatılmıştır. Penil manyetik rezonans görüntülemede penisin sağında olan ve penisi sola deviye eden 5x4,5 cm boyutlarında apse izlendi. Penil apse; eksplorasyon, insizyon, drenaj ve intravenöz antibiyotikler ile başarılı bir şekilde tedavi edildi. Operasyondan 6 ay sonra penil protez takıldı.

Anahtar Kelimeler: Penil apse, İntrakavernozal enjeksiyon, Erektil disfonksiyon

\section{Introduction}

Penile abscess is a rare clinical condition. Symptoms include swelling, pain and local increase in temperature. Among the causes of penile abscess, trauma, foreign body, perianal and perineal abscess drainage, extension of intraabdominal abscess, tuberculosis, priapism, and hematogenous dissemination of periodontal abscess may be listed. Penile abscess may also develop spontaneously $(1,2)$. Diabetic patients are at greater risk for penile abscesses. Staphylococcus aureus, Streptococci, Bacteroides, and Enterococci are the most common microorganisms leading to formation of penile abscess.

Cavernosography, ultrasonography (US), magnetic resonance imaging (MRI) and computed tomography (CT) are useful diagnostic tools (3). Penile abscess can be successfully treated with incision and drainage combined with systemic antibiotics. Successful treatment with aspiration alone has also been described by some authors $(1,3,4)$. We present a case of a paraplegic and parastetic patient who developed a penile abscess due to intracavernosal papaverine injections.

\section{Case Presentation}

A 45-year-old patient with spinal cord injury at T12 due to a car accident in 1998 is presented. He had lost both motor and sensory functions in the lower extremities. He was admitted with the complaint of penile swelling. His medical history revealed self-administration of intracavernous papaverine injections for the past 3 years due to erectile dysfunction (ED). At admission, his primary complaint was being unable to apply injections because of swelling. He noticed the swelling 2 months ago, but since he had no pain he did not seek any medical care. On physical examination, severe swelling was detected at the right side of the penis, shifting the corpus to the left side (Figure 1). A mass of $5 \mathrm{~cm}$ in size was palpated at the swollen area. In order to differentiate hematoma from abscess, penile MRI was performed. On the right side of the corpus cavernosum, beneath

Correspondence: Yalçın Kızılkan MD, Başkent University Faculty of Medicine, Department of Urology, Ankara, Turkiye

E-mail: yalcinkizilkan@yahoo.com ORCID-ID: orcid.org/0000-0002-4729-0100

Received: 31.10.2017 Accepted: 12.12.2017

Cite this article as: Kızılkan Y, Duran MB, Peşkircioğlu ÇL. Penile Abscess Due to Intracavernosal Injection: A Case Report. J Urol Surg 2018;5(4):214-216.

๑Copyright 2018 by the Association of Urological Surgery / Journal of Urological Surgery published by Galenos Publishing House. 
the tunica albuginea, there was an abscess measuring $50 \times 45 \mathrm{~mm}$ in size. The abscess caused significant compression and edema in the corpus cavernosum and corpus spongiosum (Figure 1). After intravenous ciprofloxacin treatment was started, the patient was immediately taken into surgical intervention. A circular incision performed at the dorsum of the penis revealed the abscess and 20-25 $\mathrm{mL}$ of pus was drained (Figure 2). After pus specimen collection, the abscess region was irrigated with saline. A Minivac drain was inserted into the abscess area for drainage. S. aureus was isolated and the antibiotic treatment was continued. Following the removal of the drainage catheter, the patient was discharged at the $2^{\text {nd }}$ postoperative day. Six months after the drainage of abscess, it was decided to implant a penile prosthesis in order to treat ED and to avoid further intracavernosal injections. A malleable penile prosthesis was preferred as there could be a risk of complications associated with abscess drainage surgery such as fibrosis and also it was the choice of the patient. Due to tissue fibrosis and adhesions, the process of malleable penile prosthesis implantation was more complicated and took longer than expected (Figure 2).

Written and signed informed consent was obtained from the patient.

\section{Discussion}

Penile abscess is a very rare clinical entity. It may occur either in the presence of predisposing factors or spontaneously $(3,5)$. CT and US are good diagnostic tools (2). The management options for penile abscess consist of antibiotic therapy and either open surgical incision and drainage or radiologically guided needle aspiration.

Especially after the treatment of corpus cavernosum abscess, complications such as $E D$, penile deviation, and penile curvature could develop due to fibrosis and recurrence. Persistent cavernosal abscess may even lead to total penectomy and perineal urethrostomy (6). Penile abscess may be seen at any age. Up to the present, the youngest reported patient is a 24-day-old newborn who developed penile abscess after recurrent priapism (7).

Conditions causing immune suppression, especially diabetes mellitus, are among the most important predisposing factors. Besides these common underlying factors, rare causes such as intracavernous injection may also be listed. Bandi et al. (8) reported an unusual case of multiple retained needles in a 44-year-old man who presented with penile edema after
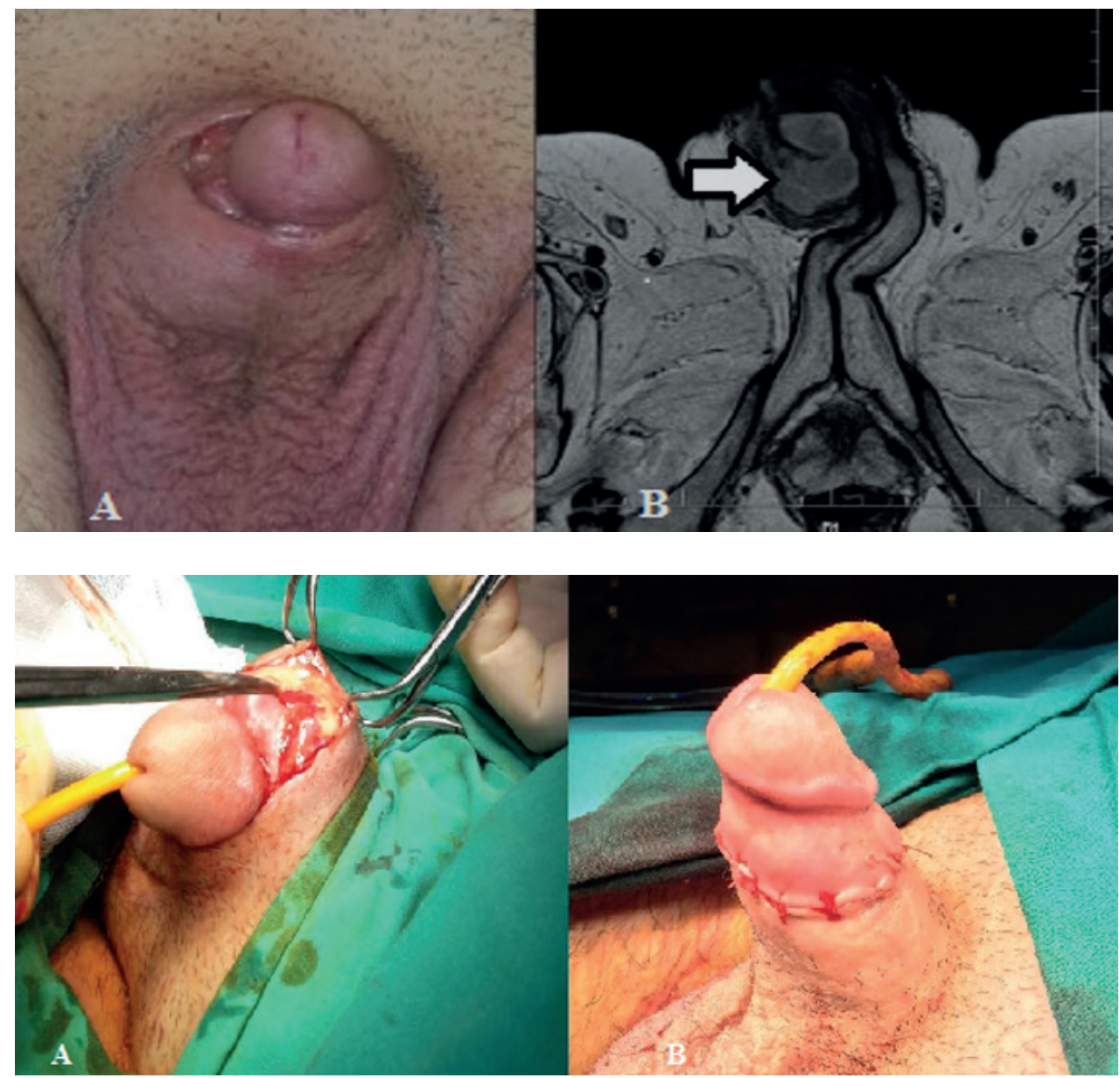

Figure 1. A) Penile abscess located at the right side of the penis, B) Penis is shifted to the left side and magnetic resonance image of the penile abscess

Figure 2. A) The insicion was performed at the dorsum of the penis for abscess drainage, B) Penile prosthesis implantation (6 months after the initial surgery) 
intracavernous self-injection complicated by needle breakage. Tüzel (9) reported a case of a healthy bodybuilder with a corpus cavernosum abscess. In this case, development of the abscess is believed to be facilitated by long-term anabolic androgenic steroid abuse (9).

During the treatment of this rare condition, one could come across with rare complications. Jinga and Iconaru (10) reported a case of a 49-year-old male with penile abscess developed following intracavernous injection which was further complicated with urethrocutaneous fistula 12 weeks after the initial treatment. Kropman et al. (4) reported a successful treatment of a corpus cavernosum abscess with percutaneous aspiration and intravenous antibiotics in a paraplegic man on intracavernous papaverine injection therapy.

Penile abscess is a rare clinical entity. Surgical drainage is the most common mode of treatment but it has risks of ED and penile deviation. Drainage with US or CT guidance should also be considered when needed. Intracavernous self-injection for paraplegic or paraphasic patients with ED should be recommended with serious instructions including all details in order to avoid such complications.

\section{Ethics}

Informed Consent: Written and signed informed consent was obtained from the patient.

Peer-review: Internally peer-reviewed.

\section{Authorship Contributions}

Surgical and Medical Practices: Y.K., M.B.D., Ç.L.P., Concept: Y.K., M.B.D., Design: Y.K., M.B.D., Data Collection or Processing: Y.K.,
M.B.D., Analysis or Interpretation: Y.K., M.B.D., Literature Search: Y.K., M.B.D., Writing: Y.K., M.B.D., Ç.L.P.

Conflict of Interest: No conflict of interest was declared by the authors.

Financial Disclosure: The authors declared that this study received no financial support.

\section{References}

1. Dugdale CM, Tompkins AJ, Reece RM, Gardner AF. Cavernosal Abscess due to Streptococcus Anginosus: A Case Report and Comprehensive Review of the Literature. Curr Urol 2013;7:51-56.

2. Thanos L, Tsagouli P, Eukarpidis T, Mpouhra K, Kelekis D. Computed tomography-guided drainage of a corpus cavernosum abscess: a minimally invasive successful treatment. Cardiovasc Intervent Radiol 2011;34:217-219.

3. Brennan J, O'Kelly F, Quinlan DM. A case of spontaneous abscess of the corpus cavernosum. Scand J Urol 2013;47:534-536.

4. Kropman RF, de la Fuente RB, Venema PL, van Imhoff WL. Treatment of corpus cavernosum abscess by aspiration and intravenous antibiotics. J Urol 1993;150:1502-1503.

5. Sagar J, Sagar B, Shah DK. Spontaneous penile (cavernosal) abscess: case report with discussion of aetiology, diagnosis, and management with review of literature. ScientificWorldJournal 2005;5:39-41.

6. Ehara H, Kojima K, Hagiwara N, Phuoc NB, Deguchi T. Abscess of the corpus cavernosum. Int J Infect Dis 2007;11:553-554.

7. Sood R, Wadhwa SN, Jain V. Neonatal priapism associated with spontaneous bilateral pyocavernositis. Ann Acad Med Singapore 2006;35:425-427.

8. Bandi G, Rajpurkar A, MacDonald MF, Dhabuwala CB. Multiple retained needles: an unusual complication of intracavernous self-injection. Urology 2005;65:797.

9. Tüzel E. Spontaneous corpus cavernosum abscess in a healthy man using long-term androgenic anabolic steroids. World J Mens Health 2015;33:36-38.

10. Jinga V, Iconaru V. Penile abscess and urethrocutaneous fistula following intracavernous injection: a case report. J Sex Med 2012;9:3270-3273. 